\title{
Geochronology of zircon megacrysts from nepheline-bearing gneisses as constraints on tectonic setting: implications for resetting of the $\mathrm{U}-\mathrm{Pb}$ and Lu-Hf isotopic systems
}

\author{
L. D. Ashwal · R. A. Armstrong $\cdot$ R. J. Roberts $\cdot$ M. D. Schmitz $\cdot$ F. Corfu $~$ \\ C. J. Hetherington $\cdot$ K. Burke $\cdot$ M. Gerber
}

Received: 20 December 2005/ Accepted: 29 September 2006/ Published online: 9 December 2006

(C) Springer-Verlag 2006

\begin{abstract}
Nepheline-bearing gneisses from the $75 \mathrm{~km}^{2}$ Tambani body in the Mozambique Belt of southern Malawi, are miaskitic biotite-nepheline monzodiorites, reflecting an absence of K-feldspar, alkali amphiboles or pyroxenes, and contain euhedral zircon megacrysts up to $5 \mathrm{~cm}$ across. The zircons contain $\mathrm{U}=1-1,860 \mathrm{ppm}, \quad \mathrm{Th}=0-2,170 \mathrm{ppm} \quad$ and $\mathrm{Y}=400-1,100 \mathrm{ppm}$, and very low concentrations of all other measured trace elements except $\mathrm{Hf}\left(\mathrm{HfO}_{2}=\right.$ 0.53-0.92 wt. \%). Cathodoluminescence images reveal
\end{abstract}

Communicated by T.L. Grove.

L. D. Ashwal $(\bowtie) \cdot$ R. J. Roberts · K. Burke · M. Gerber School of Geosciences, University of the Witwatersrand, Private Bag 3, WITS 2050 Johannesburg, South Africa e-mail: ashwall@geosciences.wits.ac.za

\section{R. J. Roberts}

e-mail: james@armoury.co.za

K. Burke

e-mail: burke@dtm.ciw.edu

M. Gerber

e-mail: madsgerber@yahoo.com

\section{R. A. Armstrong}

Research School of Earth Sciences,

The Australian National University,

Mills Road, Canberra 0200 ACT, Australia

e-mail: Richard.Armstrong@anu.edu.au

\section{D. Schmitz · K. Burke}

Department of Terrestrial Magnetism,

Carnegie Institution of Washington,

5241 Broad Branch Road, Washington,

DC 20015, USA

M. D. Schmitz

e-mail: markschmitz@boisestate.edu oscillatory sector growth zoning and no evidence for xenocrystic cores, indicating that the zircons represent primary magmatic crystallization products that have survived amphibolite grade metamorphism. U-Pb isotopic analyses (by TIMS) yield an upper intercept age of $730 \pm 4 \mathrm{Ma}(\mathrm{MSWD}=1.7)$, which we interpret as the time of magmatic crystallization of the zircons. This is coincident with 11 SHRIMP spot analyses, which yield a mean age of $729 \pm 7$ Ma (MSWD $=0.37$ ). Metamorphism, at $522 \pm 17 \mathrm{Ma}$ as suggested by monazite, caused partial Pb-loss during local recrystallization of zircon. Lu-Hf isotopic data for three whole-rock

K. Burke

e-mail: burke@dtm.ciw.edu

F. Corfu

Department of Geosciences, University of Oslo,

P.O. Box 1047, Blindern, 0316 Oslo, Norway

e-mail: Fernando.corfu@geo.uio.no

\section{J. Hetherington}

Department of Geosciences,

University of Massachusetts, 611 North Pleasant Street,

Amherst, MA 01003-9297, USA

e-mail: callum@geo.umass.edu

K. Burke

Department of Geosciences, University of Houston, Houston, TX 77204-5007, USA

e-mail: burke@dtm.ciw.edu

Present Address:

M. D. Schmitz

Department of Geosciences, Boise State University,

1910 University Drive, Boise, ID 83725-1535, USA

e-mail: markschmitz@boisestate.edu 
samples of nepheline-bearing gneiss are collinear with those for zircon megacrysts, and correspond to an age of $584 \pm 17$ Ma (MSWD $=0.37$. We interpret the Lu$\mathrm{Hf}$ array to represent a mixing line defined by the Hf isotopic signature of primary zircon and that of the rock-forming minerals reset during metamorphic (re-)crystallization; hence the $584 \mathrm{Ma}$ age is likely geologically meaningless. Given the well-defined association of nepheline syenites (and phonolitic volcanic equivalents) with continental rifting, we suggest that the Tambani body represents a magmatic product formed at 730 Ma during the break-up of the Rodinia supercontinent. The $522 \mathrm{Ma}$ age is akin to other PanAfrican metamorphic ages that record collisional suturing events during the final assembly of Gondwana. Zircon-bearing nepheline gneisses thus preserve a record of intra-continental rifting and of continental collision in southern Malawi.

\section{Introduction}

Nepheline syenites and associated alkaline and non-alkaline igneous rocks, including carbonatites, represent a minor but distinctive component of the continental crust (Sørensen 1974). Woolley (1987, $1995,2001)$ has compiled comprehensive catalogues of these rocks for North and South America, the former USSR, and Africa; a fourth volume for Asia and Europe is in preparation. Nearly all occurrences of these rocks and their volcanic equivalents have been clearly associated with continental rifts (Bailey 1974, 1977, 1992), but deformed examples were suggested by Burke et al. (2003) to represent rift-related magmatic rocks that had later been involved in continent-continent or arc-continent collision. Deformed alkaline rocks and (to a lesser extent) carbonatites (DARCs) commonly contain zircon, and represent promising targets for precise geochronology. It seems possible that they might preserve a record of both rifting and collision. Parrish and Scammell (1988) (see also Parrish and Noble 2003) applied TIMS U-Pb methods to zircons and distinguished magmatic from metamorphic ages in metamorphosed nepheline syenites and carbonatites from British Columbia. Johnston et al. (2003) subsequently applied a rifting and collisional interpretation to these and similar rocks elsewhere in British Columbia.

Some nepheline syenite occurrences are known to contain large, euhedral zircon crystals up to several $\mathrm{cm}$ across. These zircon megacrysts are present in both deformed and undeformed bodies. Deformed exam- ples include Tambani, southern Malawi (Cooper and Bloomfield 1961; this study), Bull's Run, South Africa (Scogings and Forster 1989; Nicolaysen and Burger 1965), Peixe, Brazil (Kitajima et al. 2001) and Darkainle, Somalia (Gellatly and Hornung 1968). Undeformed occurrences include Puttetti, India (Nair and Santosh 1985; Miyazaki and Santosh 2005) and Seiland, northern Norway (Pedersen et al. 1989). In addition, zircons up to $30 \mathrm{~cm}$ across can be found in some carbonatites (Corfu et al. 2003). In this paper we use U-Pb isotopic data (TIMS and SHRIMP) for zircon megacrysts and monazite from the Tambani occurrence of southern Malawi, as well as Lu-Hf whole-rock isotopic data, to test the idea that the ages of rifting and collision for this nepheline-bearing gneiss body can be measured.

\section{Geology and sampling}

In southwestern Malawi (Figs. 1, 2), an elongate mass of nepheline-bearing gneiss $\sim 75 \mathrm{~km}^{2}$ in area forms the Tambani body (in some works also spelled "Thambani", Cooper and Bloomfield 1961). The nephelinebearing gneisses are characterized by alternating bands of varying colour index (\% mafic minerals) on a centimetre scale. Coarser bands contain large nepheline crystals up to $7 \mathrm{~cm}$ across. That the fabric of the

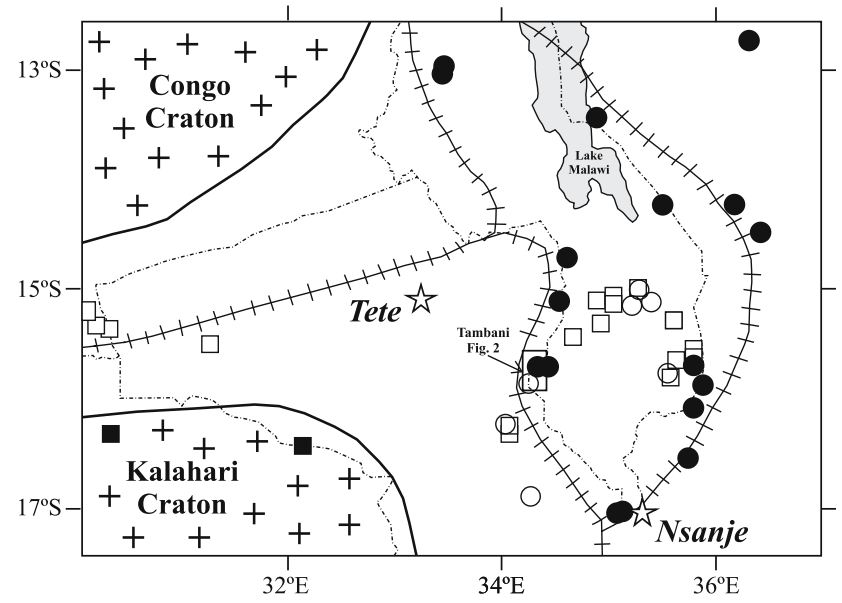

Fig. 1 Alkaline rocks, carbonatites, cratons, Pan-African fold belts and suture zones in southern Africa (modified from Burke et al. 2003). Circles nepheline syenites; squares carbonatites; open symbols undeformed occurrences (ARCs); filled symbols deformed (DARCs) occurrences. Extent of Congo and Kalahari Cratons is indicated by + symbols. Unpatterned areas represent Pan-African rocks in the Damara-Lufilian-Zambezi (DLZB) and Mozambique (MB) fold belts. Suture patterns (lines with bars) are based on distribution of DARCs, regional geology and geophysics. International boundaries are indicated by dash-dot lines. Location of the Tambani nepheline-bearing gneiss locality (Fig. 2) is indicated 


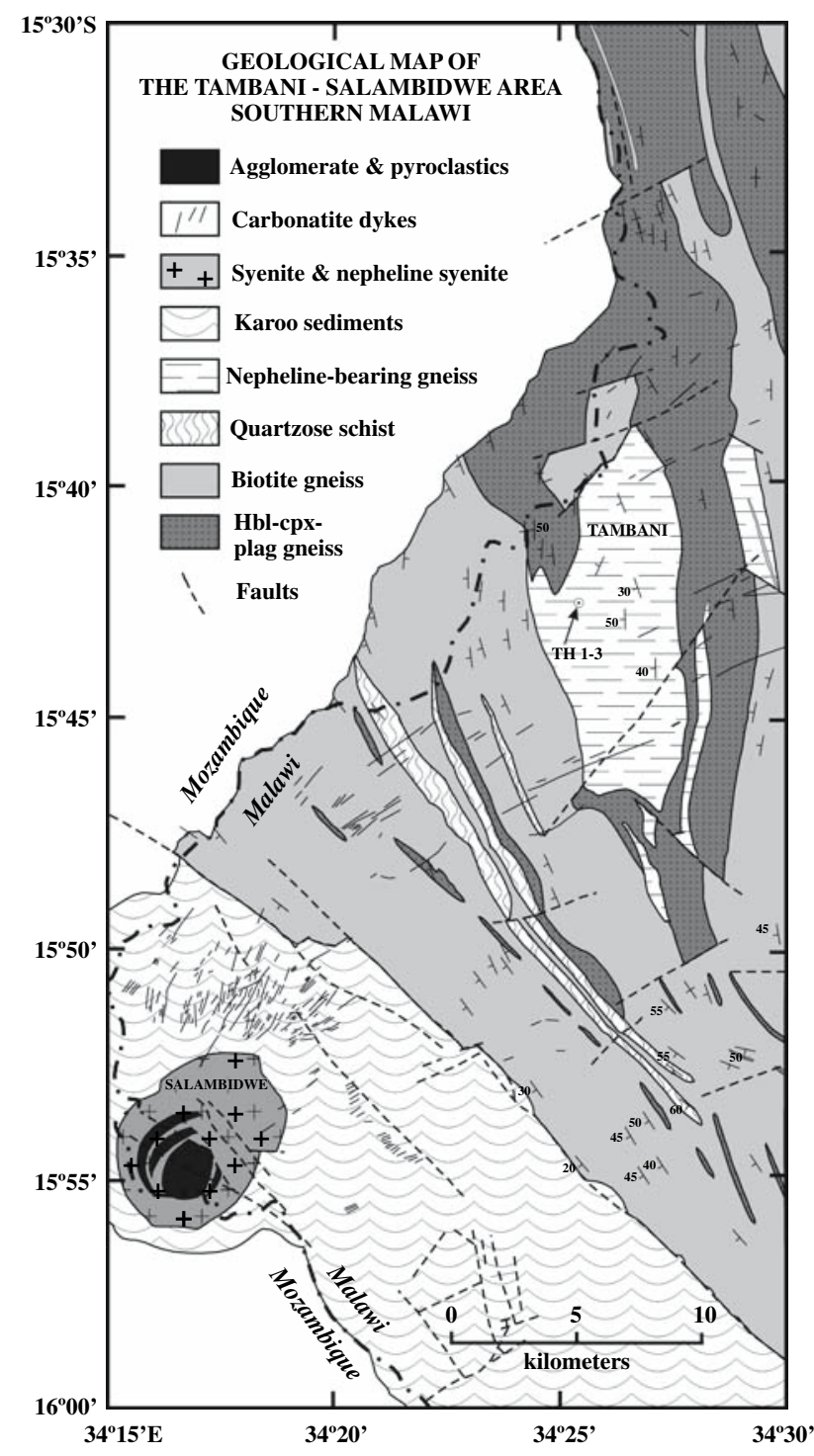

Fig. 2 Geological map of the Tambani-Salambidwe area, southern Malawi and northern Mozambique, adapted from Cooper and Bloomfield (1961). The sample locality in the Tambani nepheline-bearing gneiss body is shown as TH $1-3$. About $15 \mathrm{~km}$ southwest of Tambani lies the post-Triassic Salambidwe intrusion, a circular ring complex of phonolitic trachytes, agglomerates, pulaskites and assorted alkaline syenites (Garson 1965). Tambani and Salambidwe represent a good example of recurring alkaline magmatism over long periods of geological time in a spatially restricted area, as discussed by Burke et al. (2003)

nepheline-bearing rocks is metamorphic and not magmatic was emphasized by Cooper and Bloomfield (1961). Mineralogically, the Tambani rocks consist of varying proportions of plagioclase, nepheline, biotite, muscovite, and zircon, with or without accessory corundum, apatite, magnetite and calcite. Obviously it is important, as the map shows (Fig. 2), to emphasize the concordance of the Tambani body with the country rocks, which include dominantly biotite- and/or horn- blende-bearing paragneisses and quartz-muscovite schists. To the north of the Tambani body the country rocks are dominated by hornblende-clinopyroxeneplagioclase gneisses, which may represent metavolcanics or metabasic intrusives (Cooper and Bloomfield 1961).

Some of the Tambani nepheline-bearing gneisses contain euhedral zircon crystals up to $5 \mathrm{~cm}$ (Fig. 3a). Near our sampling locality (Fig. 2) an entrepreneurial venture has been set up in which villagers collect and stockpile zircon crystals that have weathered out in fields; some 60 tons of zircon have been amassed to date (Fig. 3b). That these zircons were originally derived from the surrounding nepheline-bearing gneisses is demonstrated by the presence of similar crystals within the gneisses (Fig. 3c). The in situ zircon megacrysts have commonly produced haloes of radiation damage in surrounding host minerals (Fig. 3c). A smaller quantity of corundum crystals up to several centimetres across has also been recovered.

The zircons are typically euhedral to subhedral, with well-developed bipyramidal forms, and less-developed prismatic faces, yielding subequant crystal shapes (Fig. 3a). Their colour is typically brown to darkbrown. Some of these zircons were amongst those used for age determinations by $\mathrm{Pb}-\alpha$ methods (Cooper and Bloomfield 1961) to demonstrate a Precambrian age for the Tambani body. Results for 6 zircon specimens ranged between 515 and $659 \mathrm{Ma}$, and an age of 542 was determined for a single monazite specimen. In this paper we report Lu-Hf isotopic data that yield an age well within error of these results, but our U-Pb zircon analyses produce a significantly older age. Specimens of nepheline-bearing gneiss for whole-rock chemical and Lu-Hf isotopic analysis were taken from the locality shown in Fig. 2. Zircon specimens for U-Pb isotopic analysis were collected from the large stockpile nearby.

\section{Analytical methods}

Three whole-rock samples of $0.5-1 \mathrm{~kg}$ mass and two zircon megacrysts $(2-3 \mathrm{~cm}$ across) were crushed using a steel jaw crusher and ring mill, and were pulverized with an agate mortar and pestle at the University of the Witwatersrand. Major and selected trace element concentrations were determined by XRF at the School of Geosciences, University of the Witwatersrand, using standard techniques (Norrish and Hutton 1969; Feather and Willis 1976). Data are given in Tables 1 and 2. Lu-Hf isotopic and concentration measurements (Table 3) were carried out at the Carnegie Institution of Washington, Department of Terrestrial Magnetism. 


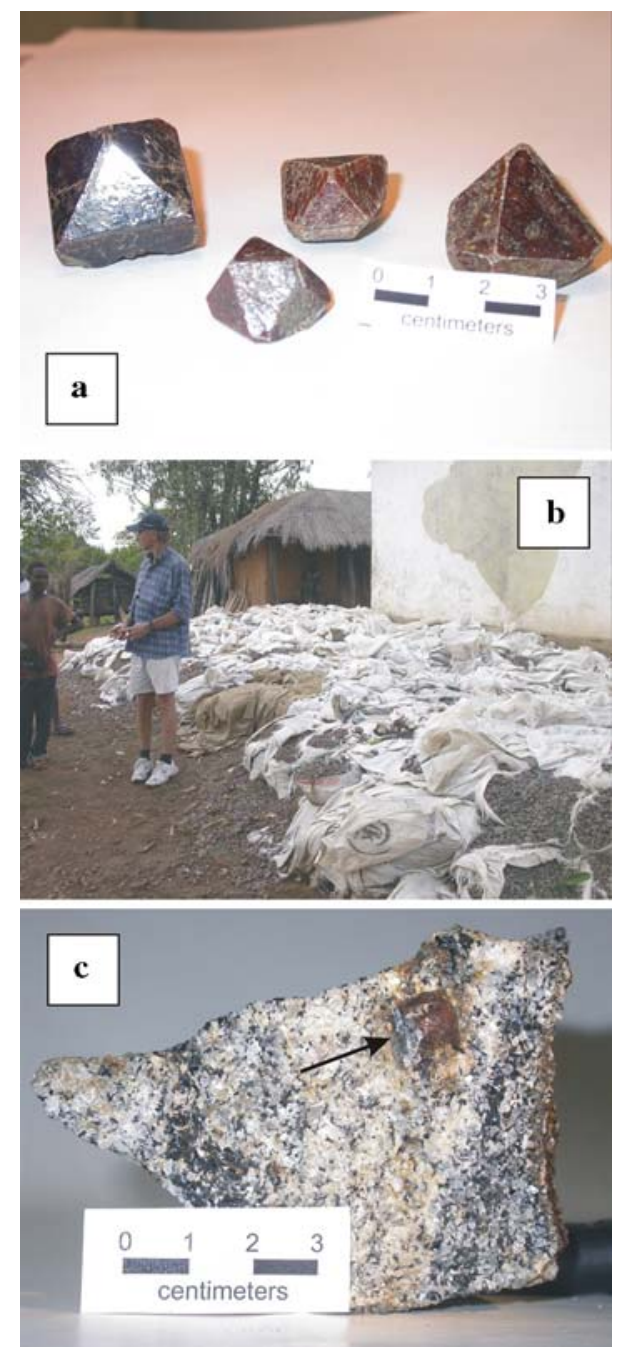

Fig. 3 a Selected specimens of zircon megacrysts from the Tambani nepheline-bearing gneiss body at the stockpile shown in b where villagers have accumulated $\sim 60$ tons of material from local fields. Specimen of nepheline-bearing gneiss in $\mathbf{c}$ shows in situ zircon megacryst (arrow) with $2-3 \mathrm{~mm}$ radiation halo affecting surrounding host (upper right)

$\mathrm{U}-\mathrm{Pb}$ zircon analyses by thermal ionization mass spectrometry (TIMS, Table 4) were obtained at the University of Oslo, and sensitive high resolution ion microprobe (SHRIMP, Table 5) data were collected at the Australian National University.

$\mathrm{Lu}$ and $\mathrm{Hf}$ were separated by standard cation exchange chemistry (initial elution of $\mathrm{Hf}$ in $1 \mathrm{M}$ $\mathrm{HCl}+0.1 \mathrm{M} \mathrm{HF}$; Lu following $\mathrm{Rb}-\mathrm{Sr}$ separation by elution in $4 \mathrm{M} \mathrm{HCl}$ on $6 \mathrm{~mm}$ i.d. $\times 20 \mathrm{~cm}$ columns of AG-50W-X8 resin, $\mathrm{H}^{+}$form, 200-400 mesh, after Patchett and Tatsumoto 1980). Hf was further purified by the method of Munker et al. (2000) on $6 \mathrm{~mm}$ i.d. $\times$ $3.5 \mathrm{~cm}$ columns of Eichrom Ln-spec resin (HDEHPcoated resin, 100-200 mesh); Lu was separated from the bulk of $\mathrm{Yb}$ by elution with $2.5 \mathrm{M} \mathrm{HCl}$ on $4 \mathrm{~mm}$ i.d. $\times 7.2 \mathrm{~cm}$ columns of Eichrom Ln-spec resin. Lu and $\mathrm{Hf}$ isotopes were measured on the P54 MC-ICPMS in static Faraday mode. Instrumental mass fractionation of Hf isotopes was corrected with an exponential law relative to ${ }^{179} \mathrm{Hf} /{ }^{177} \mathrm{Hf}=0.7325$. The ${ }^{176} \mathrm{Lu} /{ }^{177} \mathrm{Hf}$ ratio is reported as spike-stripped and bias-corrected relative to the accepted value of the JMC-475 standard (0.282160, Blichert-Toft et al. 1997). The quoted uncertainty for each analysis is the internal standard error; the external reproducibility of the JMC-475 standard over the course of this study was $0.282156 \pm$ $14(2 \sigma)$. Mass fractionation of the ${ }^{176} \mathrm{Lu} /{ }^{175} \mathrm{Lu}$ ratio was corrected using the mass bias in ${ }^{173} \mathrm{Yb} /{ }^{174} \mathrm{Yb}$, renormalized to a value of 0.5075 (McCulloch et al. 1997), and the ${ }^{176} \mathrm{Yb}$ isobaric interference was corrected using a value of ${ }^{173} \mathrm{Yb} /{ }^{176} \mathrm{Yb}=0.7848$, which optimally recovered the true ${ }^{176} \mathrm{Lu} /{ }^{175} \mathrm{Lu}$ of variably $\mathrm{Yb}$-doped natural and spike Lu standards. Uncertainty in $\mathrm{Lu}$ and Hf concentrations and ${ }^{176} \mathrm{Lu} /{ }^{177} \mathrm{Hf}$ are estimated at $\leq 0.3 \%(2 \sigma)$. Lu-Hf isotopic and concentration data are given in Table 3. Age calculations were performed using a decay constant for ${ }^{176} \mathrm{Lu}$ of $1.865 \times 10^{-11} \mathrm{y}^{-1}$ derived by cross-calibrating against $\mathrm{U}-\mathrm{Pb}$, through simultaneous analysis of high and low Lu/Hf accessory minerals dated by U-Pb methods (Scherer et al. 2001).

$\mathrm{U}-\mathrm{Pb}$ analyses by isotope dilution TIMS were conducted at the University of Oslo, following the methods of Krogh (1973). The eight zircon fragments analysed are pieces that were broken off a thin slice cut through the centre of a large $(-3.5 \mathrm{~cm}$ across $)$ crystal. Sparse monazite (less than ten grains), yellowish and transparent, along many grains of zircon was found in the mineral separates of sample TH-1. Because of its scarcity and fragility the monazite was not abraded whereas the zircon fragments were air-abraded to remove altered rims (Krogh 1982). Cleaning was done with dilute nitric acid, followed by de-ionized water and acetone rinses. The zircon fragments were then dissolved in $\mathrm{HF}$ $\left(+\mathrm{HNO}_{3}\right)$ in Teflon bombs at $184^{\circ} \mathrm{C}$ and monazite with $6 \mathrm{~N} \mathrm{HCl}$ in Savillex vials at $120^{\circ} \mathrm{C}$, along with a measured amount of ${ }^{205} \mathrm{~Pb} /{ }^{235} \mathrm{U}$ spike. The solutions were passed through ion exchange resin using $\mathrm{HCl}$ for zircon and $\mathrm{HCl}-\mathrm{HBr}$ for monazite. The samples were then analysed on a Finnigan MAT 262 mass spectrometer, using both static Faraday cups and dynamic counting, using a secondary ion-counting electron multiplier (SEM). Corrections for isotopic fractionation and SEM analytical bias were performed prior to correcting the analyses for initial common $\mathrm{Pb}$ content (Stacey and Kramers 1975). The U-Pb concentration and isotopic data are given in Table 3. Age regressions for $\mathrm{U}-\mathrm{Pb}$ and $\mathrm{Lu}-\mathrm{Hf}$ isotopic data were carried out using the program ISOPLOT (Ludwig 1999). 
Table 1 Whole-rock major and trace element data for Tambani nepheline-bearing gneisses

\begin{tabular}{|c|c|c|c|c|c|c|}
\hline & \multicolumn{3}{|c|}{ Sample no. (this study) } & \multicolumn{3}{|c|}{ Cooper and Bloomfield (1961) } \\
\hline & TH-2 & TH-3 & TH-5 & & & \\
\hline $\mathrm{SiO}_{2}$ & 57.91 & 58.29 & 58.09 & 56.24 & 58.18 & 57.56 \\
\hline $\mathrm{TiO}_{2}$ & 0.40 & 0.46 & 0.40 & 0.06 & 0.04 & 0.13 \\
\hline $\mathrm{Al}_{2} \mathrm{O}_{3}$ & 21.96 & 21.95 & 22.12 & 24.65 & 22.68 & 21.4 \\
\hline $\mathrm{Fe}_{2} \mathrm{O}_{3}^{\mathrm{a}}$ & 0.73 & 0.89 & 0.71 & 0.51 & 1.04 & 1.11 \\
\hline $\mathrm{FeO}^{\mathrm{a}}$ & 3.74 & 4.54 & 3.60 & 2.44 & 2.27 & 5.51 \\
\hline $\mathrm{MnO}$ & 0.09 & 0.14 & 0.10 & 0.03 & 0.08 & 0.26 \\
\hline $\mathrm{MgO}$ & 0.38 & 0.47 & 0.40 & 0.17 & 0.04 & 0.01 \\
\hline $\mathrm{CaO}$ & 1.83 & 1.15 & 1.69 & 0.54 & 0.33 & 1.42 \\
\hline $\mathrm{Na}_{2} \mathrm{O}$ & 7.50 & 8.45 & 9.05 & 11.19 & 9.34 & 6.97 \\
\hline $\mathrm{K}_{2} \mathrm{O}$ & 2.29 & 2.50 & 2.18 & 2.96 & 4.54 & 4.22 \\
\hline $\mathrm{P}_{2} \mathrm{O}_{5}$ & 0.29 & 0.33 & 0.16 & 0.02 & 0.08 & 0.09 \\
\hline LOI & 1.03 & 0.70 & 1.14 & 0.66 & 0.67 & 1.19 \\
\hline Total & 98.15 & 99.86 & 99.64 & 99.47 & 99.29 & 99.87 \\
\hline$(\mathrm{Na}+\mathrm{K}) / \mathrm{Al}$ & 0.67 & 0.76 & 0.78 & 0.88 & 0.89 & 0.75 \\
\hline $\mathrm{Mg} \#^{\mathrm{a}}$ & 0.15 & 0.16 & 0.17 & 0.11 & 0.03 & 0.00 \\
\hline $\mathrm{Rb}$ & 89 & 112 & 89 & & & \\
\hline $\mathrm{Sr}$ & 1,639 & 1,427 & 1,678 & & & \\
\hline $\mathrm{Y}$ & 7 & 13 & 8 & & & \\
\hline $\mathrm{Zr}$ & $<3$ & 38 & 17 & & & \\
\hline $\mathrm{Nb}$ & 110 & 155 & 108 & & & \\
\hline $\mathrm{Co}$ & 3 & $<6$ & 10 & & & \\
\hline $\mathrm{Ni}$ & $<6$ & $<6$ & 14 & & & \\
\hline $\mathrm{Cu}$ & $<9$ & $<6$ & 2,979 & & & \\
\hline $\mathrm{Zn}$ & 103 & 129 & 102 & & & \\
\hline V & $<12$ & 14 & 13 & & & \\
\hline $\mathrm{Cr}$ & 30 & 42 & 43 & & & \\
\hline $\mathrm{Ba}$ & 2,078 & 2,125 & 1,908 & & & \\
\hline $\mathrm{Pb}$ & & 9 & 11 & & & \\
\hline $\mathrm{Ga}$ & & 24 & 23 & & & \\
\hline $\mathrm{Sc}$ & & $<10$ & $<10$ & & & \\
\hline Th & & $<15$ & $<15$ & & & \\
\hline $\mathrm{Hf}$ & & $<10$ & $<10$ & & & \\
\hline $\mathrm{Ta}$ & & $<10$ & 13 & & & \\
\hline As & & $<9$ & $<9$ & & & \\
\hline Mo & & $<6$ & $<6$ & & & \\
\hline $\mathrm{Cs}$ & & 13 & 11 & & & \\
\hline $\mathrm{U}$ & & $<6$ & $<6$ & & & \\
\hline $\mathrm{La}$ & & 36 & 18 & & & \\
\hline $\mathrm{Ce}$ & & 66 & 31 & & & \\
\hline $\operatorname{Pr}$ & & $<12$ & $<12$ & & & \\
\hline $\mathrm{Nd}$ & & 32 & 13 & & & \\
\hline $\mathrm{Sm}$ & & $<12$ & $<12$ & & & \\
\hline Gd & & $<12$ & $<12$ & & & \\
\hline Dy & & $<12$ & $<12$ & & & \\
\hline \multicolumn{7}{|l|}{ CIPW norms } \\
\hline Cor & 4.51 & 4.04 & 2.18 & 2.10 & 1.99 & 3.00 \\
\hline Or & 13.53 & 14.77 & 12.88 & 17.49 & 26.83 & 24.94 \\
\hline $\mathrm{Pl}$ & 70.65 & 66.48 & 67.28 & 48.54 & 47.84 & 56.52 \\
\hline $\mathrm{Ne}$ & & 4.64 & 9.01 & 26.38 & 17.50 & 4.83 \\
\hline Opx & 3.46 & & & & & \\
\hline $\mathrm{Ol}$ & 2.49 & 6.31 & 4.98 & 3.40 & 2.69 & 7.33 \\
\hline Ap & 0.63 & 0.72 & 0.35 & 0.04 & 0.17 & 0.20 \\
\hline $\mathrm{Mt}$ & 1.05 & 1.29 & 1.03 & 0.74 & 1.51 & 1.61 \\
\hline \multirow[t]{2}{*}{$\mathrm{Ilm}$} & 0.76 & 0.87 & 0.76 & 0.11 & 0.07 & 0.25 \\
\hline & 97.08 & 99.12 & 98.47 & 98.80 & 98.60 & 98.68 \\
\hline
\end{tabular}

${ }^{\mathrm{a}}$ For data in this study, $\mathrm{FeO}=85 \%$ of Fe total 
Table 2 Chemical analyses of Tambani zircons

\begin{tabular}{|c|c|c|c|c|c|c|c|c|c|c|c|}
\hline & \multicolumn{2}{|c|}{ Bulk analyses by XRF } & \multicolumn{9}{|c|}{ Microprobe analyses (see Fig. 6) } \\
\hline & Sample 1 & Sample 2 & 1 & 2 & 3 & 4 & 5 & 6 & 7 & 8 & Mean of 8 \\
\hline \multicolumn{12}{|c|}{ wt. \% oxides } \\
\hline $\mathrm{SiO}_{2}$ & 35.10 & 33.90 & 32.81 & 33.13 & 32.77 & 32.79 & 32.89 & 32.65 & 32.78 & 32.92 & 32.84 \\
\hline $\mathrm{ZrO}_{2}$ & 60.80 & 62.90 & 65.8 & 66.55 & 66.26 & 65.74 & 65.65 & 65.17 & 66.52 & 66.49 & 66.02 \\
\hline $\mathrm{HfO}_{2}$ & 0.66 & 0.92 & 0.78 & 0.66 & 0.53 & 0.56 & 0.59 & 0.57 & 0.64 & 0.60 & 0.62 \\
\hline $\mathrm{Al}_{2} \mathrm{O}_{3}$ & 1.07 & 0.70 & b.d.l. & b.d.l. & 0.002 & b.d.l. & b.d.l. & b.d.l. & b.d.l. & b.d.l. & 0.000 \\
\hline $\mathrm{Fe}_{2} \mathrm{O}_{3}^{\mathrm{a}}$ & 1.73 & 1.20 & 0.011 & 0.014 & 0.009 & 0.014 & 0.013 & 0.011 & 0.036 & 0.010 & 0.015 \\
\hline $\mathrm{MgO}$ & 0.00 & 0.12 & 0.003 & 0.005 & 0.003 & 0.003 & 0.003 & 0.003 & 0.003 & 0.003 & 0.004 \\
\hline $\mathrm{CaO}$ & 0.16 & 0.10 & 0.003 & 0.003 & 0.001 & 0.001 & 0.003 & 0.001 & 0.003 & 0.001 & 0.002 \\
\hline $\mathrm{Na}_{2} \mathrm{O}$ & 0.37 & 0.00 & b.d.l. & b.d.l. & b.d.l. & b.d.l. & b.d.l. & b.d.l. & b.d.l. & b.d.l. & 0.000 \\
\hline $\mathrm{P}_{2} \mathrm{O} 5$ & 0.00 & 0.16 & b.d.l. & b.d.l. & b.d.l. & b.d.l. & b.d.l. & b.d.l. & b.d.l. & b.d.l. & 0.000 \\
\hline $\mathrm{K}_{2} \mathrm{O}$ & 0.21 & 0.13 & 0.001 & 0.002 & b.d.l. & 0.001 & b.d.l. & 0.001 & b.d.l. & 0.002 & 0.002 \\
\hline Total & 100.11 & 100.13 & 99.41 & 100.36 & 99.58 & 99.11 & 99.15 & 98.41 & 99.98 & 100.03 & 99.50 \\
\hline \multicolumn{12}{|c|}{ Trace elements in ppm } \\
\hline $\mathrm{Y}$ & 393 & 1,100 & & & & & & & & & \\
\hline $\mathrm{La}$ & 9 & 17 & & & & & & & & & \\
\hline $\mathrm{Ce}$ & & 27 & & & & & & & & & \\
\hline $\mathrm{Nd}$ & & 11 & & & & & & & & & \\
\hline Th & 314 & 674 & 40 & 20 & 50 & 460 & 250 & 460 & 530 & 20 & \\
\hline $\mathrm{U}$ & 272 & 757 & 60 & 680 & 380 & 820 & 600 & 860 & 940 & b.d.l. & \\
\hline $\mathrm{Th} / \mathrm{U}$ & 1.154 & 0.890 & 0.667 & 0.029 & 0.132 & 0.561 & 0.417 & 0.535 & 0.564 & & \\
\hline \multicolumn{12}{|c|}{ Structural formulae per four oxygens } \\
\hline $\mathrm{Si}$ & 1.045 & 1.020 & 1.008 & 1.007 & 1.005 & 1.009 & 1.011 & 1.011 & 1.002 & 1.005 & 1.007 \\
\hline $\mathrm{Zr}$ & 0.883 & 0.923 & 0.985 & 0.987 & 0.991 & 0.986 & 0.984 & 0.984 & 0.992 & 0.990 & 0.987 \\
\hline Hf & 0.006 & 0.008 & 0.007 & 0.006 & 0.005 & 0.005 & 0.005 & 0.005 & 0.006 & 0.005 & 0.005 \\
\hline $\mathrm{Al}$ & 0.038 & 0.025 & 0.000 & 0.000 & 0.000 & 0.000 & 0.000 & 0.000 & 0.000 & 0.000 & 0.000 \\
\hline $\mathrm{Fe} 3+$ & 0.039 & 0.027 & 0.000 & 0.000 & 0.000 & 0.000 & 0.000 & 0.000 & 0.001 & 0.000 & 0.000 \\
\hline $\mathrm{Mg}$ & 0.000 & 0.005 & 0.000 & 0.000 & 0.000 & 0.000 & 0.000 & 0.000 & 0.000 & 0.000 & 0.000 \\
\hline $\mathrm{Ca}$ & 0.005 & 0.003 & 0.000 & 0.000 & 0.000 & 0.000 & 0.000 & 0.000 & 0.000 & 0.000 & 0.000 \\
\hline $\mathrm{Na}$ & 0.021 & 0.000 & 0.000 & 0.000 & 0.000 & 0.000 & 0.000 & 0.000 & 0.000 & 0.000 & 0.000 \\
\hline $\mathrm{P}$ & 0.000 & 0.004 & 0.000 & 0.000 & 0.000 & 0.000 & 0.000 & 0.000 & 0.000 & 0.000 & 0.000 \\
\hline \multirow[t]{2}{*}{$\mathrm{K}$} & 0.008 & 0.005 & 0.000 & 0.000 & 0.000 & 0.000 & 0.000 & 0.000 & 0.000 & 0.000 & 0.000 \\
\hline & 2.045 & 2.020 & 2.000 & 2.000 & 2.001 & 2.000 & 2.000 & 2.000 & 2.001 & 2.000 & 1.999 \\
\hline
\end{tabular}

$b d l$ below detection limit

a Total $\mathrm{Fe}$ as $\mathrm{Fe}_{2} \mathrm{O}_{3}$

Table $3 \mathrm{Lu}-\mathrm{Hf}$ isotopic and concentration data for Tambani samples

\begin{tabular}{|c|c|c|c|c|c|c|}
\hline \multirow{2}{*}{$\begin{array}{l}\text { Lithology } \\
\text { Sample no. }\end{array}$} & \multicolumn{3}{|c|}{ Nepheline-bearing gneisses } & \multicolumn{3}{|c|}{ Zircon megacrysts } \\
\hline & TH-2 & TH-3 & TH-5 & $78 / 52$ & $78 / 57$ & $78 / 62$ \\
\hline $\mathrm{Lu}(\mathrm{ppm})$ & 0.070 & 0.122 & 0.062 & & & \\
\hline Hf (ppm) & 0.100 & 1.215 & 0.099 & & & \\
\hline${ }^{176} \mathrm{Lu} /{ }^{177} \mathrm{Hf}$ & 0.0992 & 0.0143 & 0.0884 & & & \\
\hline${ }^{176} \mathrm{Hf} /{ }^{177} \mathrm{Hf}$ & 0.283569 & 0.282637 & 0.283437 & 0.282466 & 0.282475 & 0.282454 \\
\hline$\pm(2 \sigma)$ & 32 & 8 & 40 & 57 & 57 & 37 \\
\hline$\varepsilon_{\mathrm{Hf}}(T)^{\mathrm{a}, \mathrm{b}}$ & 2.65 & 2.56 & 2.13 & 2.04 & 2.36 & 1.61 \\
\hline$\varepsilon_{\mathrm{Hf}}(T)^{\mathrm{a}, \mathrm{c}}$ & -3.61 & 4.36 & -3.11 & 5.19 & 5.51 & 4.77 \\
\hline
\end{tabular}

a CHUR parameters: ${ }^{176} \mathrm{Lu} /{ }^{177} \mathrm{Hf}=0.0332,{ }^{176} \mathrm{Hf} /{ }^{177} \mathrm{Hf}=0.282772$

b Computed at $T=584 \mathrm{Ma}$

c Computed at $T=730 \mathrm{Ma}$

$\mathrm{U}-\mathrm{Pb}$ analyses by SHRIMP were carried out in a single session on the SHRIMP II instrument at the Research School of Earth Sciences (RSES), Australian National University. For these analyses, a single large $(2 \mathrm{~cm}$ diameter) zircon was mounted in epoxy and cut and polished to expose a full cross-section of the crystal. Grains of the RSES reference zircons FC1 and SL13 were mounted in holes cut into the zircon 


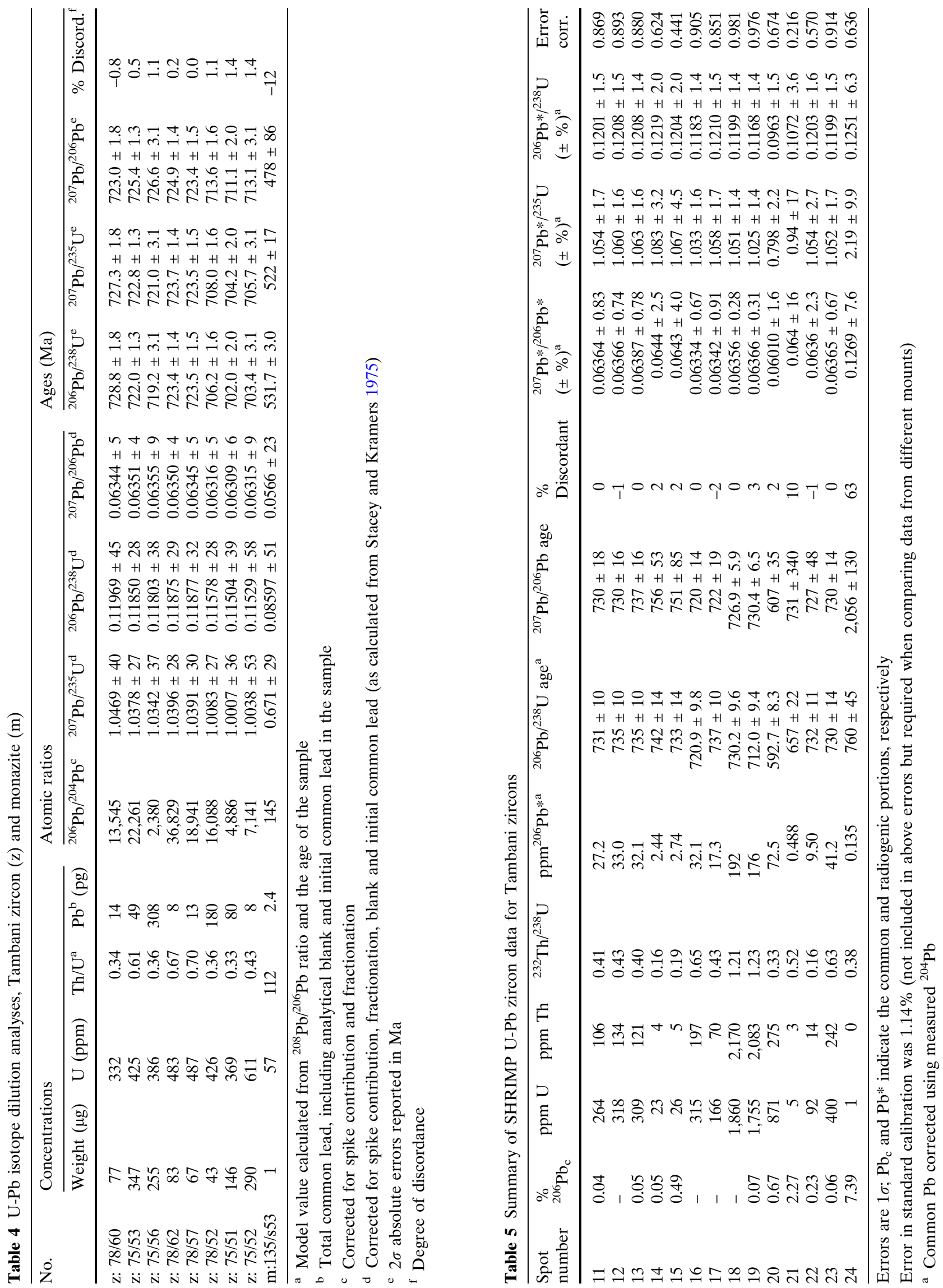


and the mount was re-polished to produce a smooth continuous surface. Photomicrographs in reflected light were taken of the whole mount, and these, together with SEM cathodoluminescence images, were used to decipher the internal structures of the sectioned zircon, and to target specific areas for spot analyses. The analytical data were reduced in a similar manner to that described by Williams (1998 and references therein), using the SQUID Excel Macro of Ludwig (2000). For the zircon calibration, the $\mathrm{Pb} / \mathrm{U}$ ratios were normalized relative to an age of 1,099 Ma (reference zircon FC1, Paces and Miller 1993). U and Th concentrations were determined relative to the SL13 standard. Corrections for common $\mathrm{Pb}$ were made using the measured ${ }^{204} \mathrm{~Pb}$ values. Some analyses were sited in zones with extremely low $U(<1 \mathrm{ppm})$ and the ${ }^{207} \mathrm{~Pb} /{ }^{206} \mathrm{~Pb}^{*}$ data are particularly sensitive to the common $\mathrm{Pb}$ correction. This, together with the low counts measured for ${ }^{207} \mathrm{~Pb}$ in particular, results in poor precision and accuracy in these calculated ${ }^{207} \mathrm{~Pb}^{*} / 206 \mathrm{~Pb}^{*}$ dates. The ${ }^{206} \mathrm{~Pb}^{*} / 238 \mathrm{U}$ dates are considered more reliable for these low- $U$ analyses. Uncertainties given for individual analyses (ratios and ages) are at the $1 \sigma$ level; however, uncertainties in the calculated weighted mean or Concordia ages (Ludwig 1998) are reported as 95\% confidence limits and include the uncertainties in the standard calibrations. Concordia plots and mean age calculations were carried out using Isoplot/Ex (Ludwig 1999).

Electron microprobe analyses of Tambani zircons were obtained with a Cameca SX-100 instrument housed at the University of Oslo. Operating conditions for major elements ( $\mathrm{Si}, \mathrm{Zr}, \mathrm{Hf})$ were as follows: accelerating voltage $=25 \mathrm{kV}$, beam current $=20$ na, and counting times of $10 \mathrm{~s}$. For trace elements ( $\mathrm{Al}, \mathrm{Fe}$, $\mathrm{Mg}, \mathrm{Ca}, \mathrm{Na}, \mathrm{P}, \mathrm{K}, \mathrm{U}, \mathrm{Th}$ ) beam current and counting time were increased to 200 na and 120 s, respectively. Standards used were as follows: $\mathrm{UO}_{2}(\mathrm{U})$, brabantite $(\mathrm{Th})$, apatite $(\mathrm{Ca}, \mathrm{P})$, plagioclase $(\mathrm{Al}, \mathrm{Si})$, fayalite $(\mathrm{Fe})$, sanidine $(\mathrm{K})$, albite $(\mathrm{Na})$, rutile $(\mathrm{Ti})$, xenotime $(\mathrm{Y})$, $\mathrm{YbO}_{4}(\mathrm{Yb}), \mathrm{CePO}_{4}(\mathrm{Ce})$, zircon ( $\left.\mathrm{Zr}\right)$, Hf metal (Hf), synthetic diopside $(\mathrm{Mg})$. A Cameca PAP-type correction procedure (Pouchou and Pichoir 1984, 1985) was used for data reduction, and any $\mathrm{Fe}$ present is expressed as $\mathrm{Fe}_{2} \mathrm{O}_{3}$ (Table 2).

\section{Results}

\section{Petrography}

The overall texture of the Tambani gneisses is granoblastic, with lathy to irregular plagioclase, irregular nepheline and prominent flakes of biotite, with lesser muscovite. The gneissic fabric is formed by weakly aligned micas and plagioclase grains. The rocks are dominated by plagioclase (70-80 modal \%), with lesser nepheline (10-20\%), biotite (10-15\%) and muscovite $(2-5 \%)$. Biotite is dark brown to dark greenish-brown. Accessory minerals include apatite, calcite and $\mathrm{Fe}-\mathrm{Ti}$ oxides (magnetite and ilmenite). K-feldspar and alkalirich amphiboles or pyroxenes are notably absent, and zircon occurs dominantly to exclusively as large megacrysts. Plagioclase is unzoned and fresh, with very minor sericitic alteration, whereas nepheline shows variable patchy alteration to very fine grained clay minerals. No obvious cancrinite was seen in our thin sections.

\section{Rock chemistry}

Whole-rock chemical analyses for major and trace elements in 3 samples of nepheline-bearing gneisses are given in Table 1. Also shown for comparison are major element data for three additional samples taken from Cooper and Bloomfield (1961). All of the Tambani samples have molar $\mathrm{Na}+\mathrm{K} / \mathrm{Al}$ ratios $<1$, and are therefore miaskitic rather than agpaitic (e.g. Sørensen 1974). This is in accordance with their plagioclase-rich mineralogy and the presence of brown biotite rather than sodic pyroxenes and/or amphiboles. On the basis of their CIPW norms (Table 1), the Tambani rocks are nepheline monzodiorites (Streckeisen 1967), reflecting the paucity of $\mathrm{K}$-feldspar (assuming that the normative sodic feldspar present is considered as plagioclase rather than alkali feldspar). Much of the $\mathrm{K}_{2} \mathrm{O}$ in these rocks is probably in biotite and muscovite, rather than in feldspars. The Mg\# is typically very low, ranging from 0 to 0.17 (Table 1), reflecting the highly fractionated character of the rocks.

The measured $\mathrm{Zr}$ concentrations of our Tambani whole-rock specimens are quite low, $<38 \mathrm{ppm}$. We avoided prominent large zircon crystals during sample preparation, and we have seen few zircons in thin sections of the samples that we analysed. Nearly all of the $\mathrm{Zr}$ in the Tambani gneisses appears, therefore, to be concentrated in the zircon megacrysts. We interpret this as a primary feature of the rocks. Most other trace elements are also present in quite low concentrations, except $\mathrm{Ba}(1,900-2,100 \mathrm{ppm})$, Sr $(1,400$ $1,700 \mathrm{ppm}), \mathrm{Rb}(90-120 \mathrm{ppm})$ and $\mathrm{Nb}(100-150 \mathrm{ppm})$ (Table 1). Light rare earth element concentrations correspond to abundance levels between 10 and 100x chondritic. 


\section{Zircon chemistry}

Chemical analyses of Tambani zircons are given in Table 2. For the bulk analyses (by XRF), the results for major elements yield reasonably good stoichiometry when recast into structural formulae; inclusions of other minerals (apatite, biotite, corundum) may account for the slightly high cation totals. Likewise, at least some of the $\mathrm{Al}, \mathrm{Fe} \mathrm{Ca}, \mathrm{Na}$ and $\mathrm{K}$ are probably contributed by mineral inclusions. This is supported by microprobe analyses, which show very low contents for all elements except $\mathrm{Si}, \mathrm{Zr}$ and $\mathrm{Hf}$ (Table 2). The $\mathrm{Hf}$ content of these zircons (0.53-0.92 wt.\% $\mathrm{HfO}_{2}$, avg. $=0.65$ wt. $\%, n=10)$ is lower than the mean $\mathrm{HfO}_{2}$ content of $1.71 \mathrm{wt} \%$ for terrestrial zircons (range 0.67.0 wt. $\% \mathrm{HfO}_{2}, n=463$ ) (Ahrens and Erlank 1969). Notable among trace elements in the Tambani zircons are the high concentrations of Y (400-1,100 ppm), Th (20-700 ppm) and U (60-760 ppm) (Table 2). The latter are comparable to $\mathrm{Th}$ and $\mathrm{U}$ concentrations determined by isotope dilution (Table 4), but SHRIMP spot analyses increases the range to $\mathrm{U}=1-$ 1,860 $\mathrm{ppm}$ and $\mathrm{Th}=0-2170 \mathrm{ppm}$ (Table 5). Th/U ratios as determined by microprobe, XRF, TIMS and SHRIMP range between 0.03 and 1.23. Zircon megacrysts with similar chemistry have been reported from the Puttetti alkali syenite body, southern India (Murali et al. 1983).

Cathodoluminescence and back-scattered electron imagery

CL and BSE images of Tambani zircons are shown in Figs. 4, 5 and 6. Growth zoning (e.g. Corfu et al. 2003) is apparent in Figs. 4 and 5a as alternating bands of variable CL emission intensity on a scale of $10-200 \mu \mathrm{m}$.
The mosaic image in Fig. 4 shows oscillatory sector zoning parallel to three crystallographic directions that correspond to externally expressed crystal faces. The $\mathrm{U}$ and Th concentrations in the zoned regions are typically $\sim 350 \mathrm{ppm}$ and $\sim 150 \mathrm{ppm}$, respectively, giving $\mathrm{Th} / \mathrm{U}$ values of $\sim 0.42$ (Table 5 ). We interpret these features to represent primary magmatic growth zoning.

Magmatically zoned zircon is crosscut by patchy and vein-like regions up to several hundred $\mu \mathrm{m}$ across, with brighter CL emission (Figs. 4, 5), and with very low $\mathrm{U}$ $(\sim 25 \mathrm{ppm})$ and $\mathrm{Th}(\sim 4 \mathrm{ppm})$ concentrations, with $\mathrm{Th} /$ $\mathrm{U}$ ratios of $\sim 0.18$ (Table 5). Also present are peculiar agate-like regions of zircon growth (Fig. 5b), with intermediate $U$ and $\mathrm{Th}$ contents (92 and $14 \mathrm{ppm}$, respectively), and similar $\mathrm{Th} / \mathrm{U}$ ratios to the vein-like material described above. SHRIMP ages of these zones yield ages indistinguishable from those of the magmatic growth zones.

Patches with very bright CL emission occur both at the edges of zircon crystals (Fig. 4) and in the vicinity of euhedral apatite crystals (Fig. 5a); the extremely low $\mathrm{U}$ and Th concentrations (as low as $1 \mathrm{ppm}$ ) of these zones renders SHRIMP geochronology difficult.

In many parts of the zircons, randomly distributed patchy areas with variable $\mathrm{CL}$ emission are present (Figs. 4, 5a, 6). One SHRIMP analysis of this material yields a young age interpreted as the time of metamorphism, as discussed below.

Electron microprobe analyses (Table 2) show a correlation between BSE brightness (which correlates inversely with CL luminescence) and $U$ and Th concentration (Fig. 6); no similar correlation is apparent with $\mathrm{HfO}_{2}$ content. The microprobe results for the irregular veins agree with the SHRIMP data, indicating that these regions are composed of zircon with lower mean atomic number (i.e. relative depletions in $\mathrm{U}, \mathrm{Th}$,

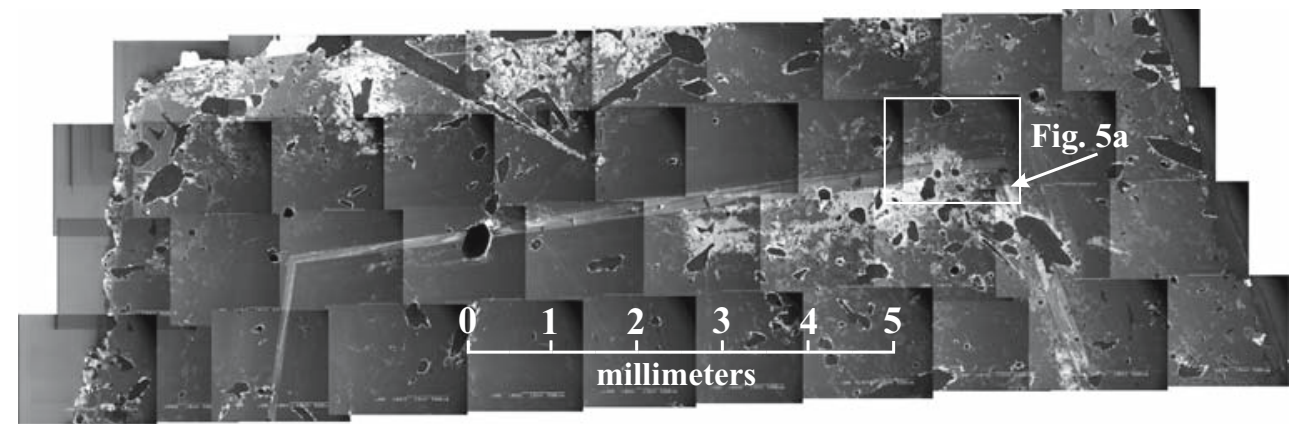

Fig. 4 Composite of 41 SEM cathodoluminescence (CL) images of a single zircon megacryst from the Tambani nepheline-bearing gneiss body, showing primary magmatic growth zoning as alternating bands of variable emission intensity, parallel to crystal faces. Also visible are patchy and vein-like zircon with brighter CL emission. Box indicates the location of the enlarged image shown in Fig. 5a. Scale bars (white) are $500 \mu \mathrm{m}$ 


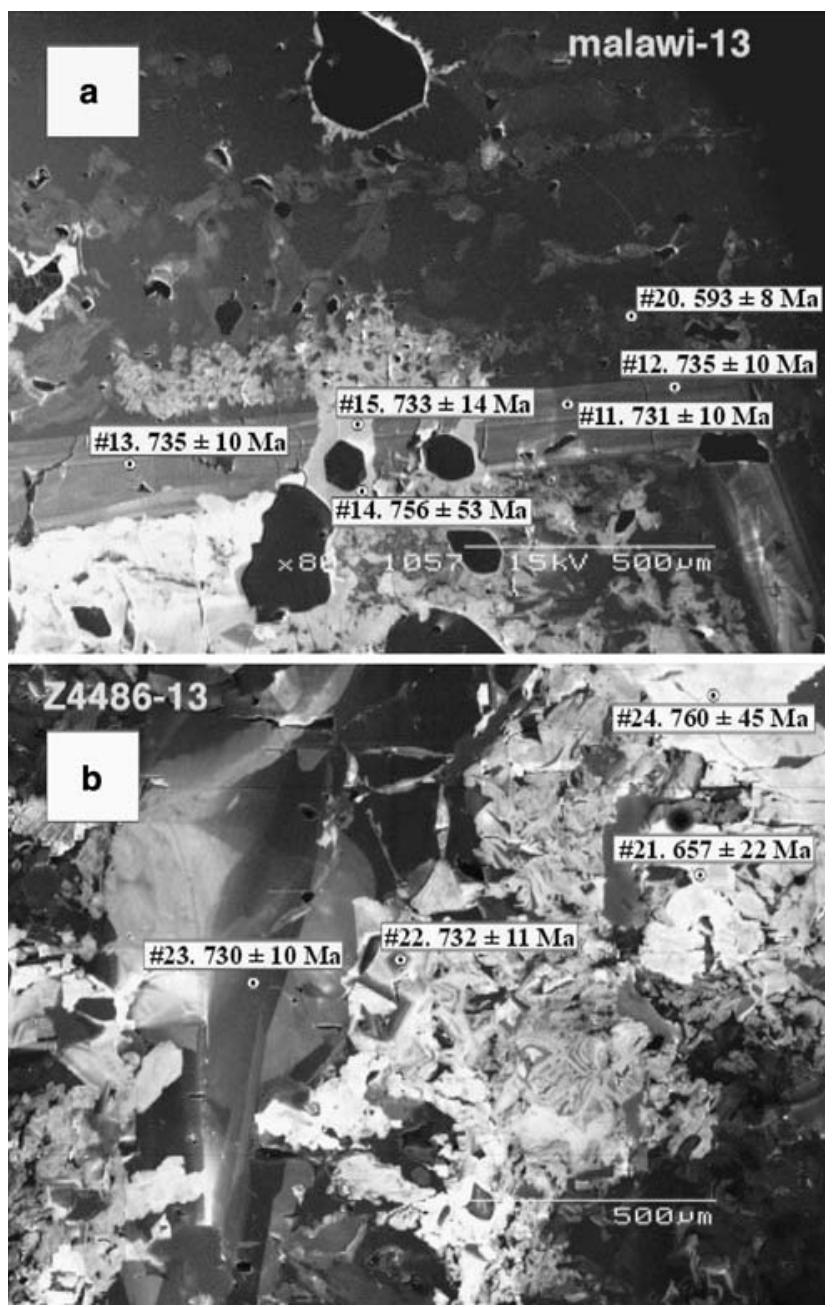

Fig. 5 Enlarged SEM cathodoluminescence (CL) images showing spot locations and ages determined by SHRIMP analysis of a Malawi zircon megacryst. Spot numbers are keyed to those given in Table 5. Image in a shows primary magmatic growth zoning (spots 11, 12,13) crosscut by vein-like zircon with higher CL luminescence (spots 14,15). Both types of zircon yield ages interpreted as that of magmatic crystallization. Patchy zircon surrounds the oscillatory zoned zircon (e.g. spot 20), and yields a substantially younger age. Dark equant areas (e.g. between spots 14 and 15) are inclusions of apatite. Image in $\mathbf{b}$ shows peculiar agate-like growth patterns (spot 22); these regions yield ages indistinguishable from those interpreted as representing magmatic crystallization. Patches with very bright CL emission (spots $21,24)$ contain very low $U$ and Th concentrations, resulting in imprecise ages

HREE etc.) compared to their surrounding host zircon. No obvious metamictization or alteration is present in the Tambani zircons.

\section{$\mathrm{U}-\mathrm{Pb}$ geochronology (TIMS)}

TIMS U-Pb isotopic analyses of Tambani zircon are shown in a Concordia diagram in Fig. 7. Five of the zircon analyses plot in a group with less than $1.1 \%$
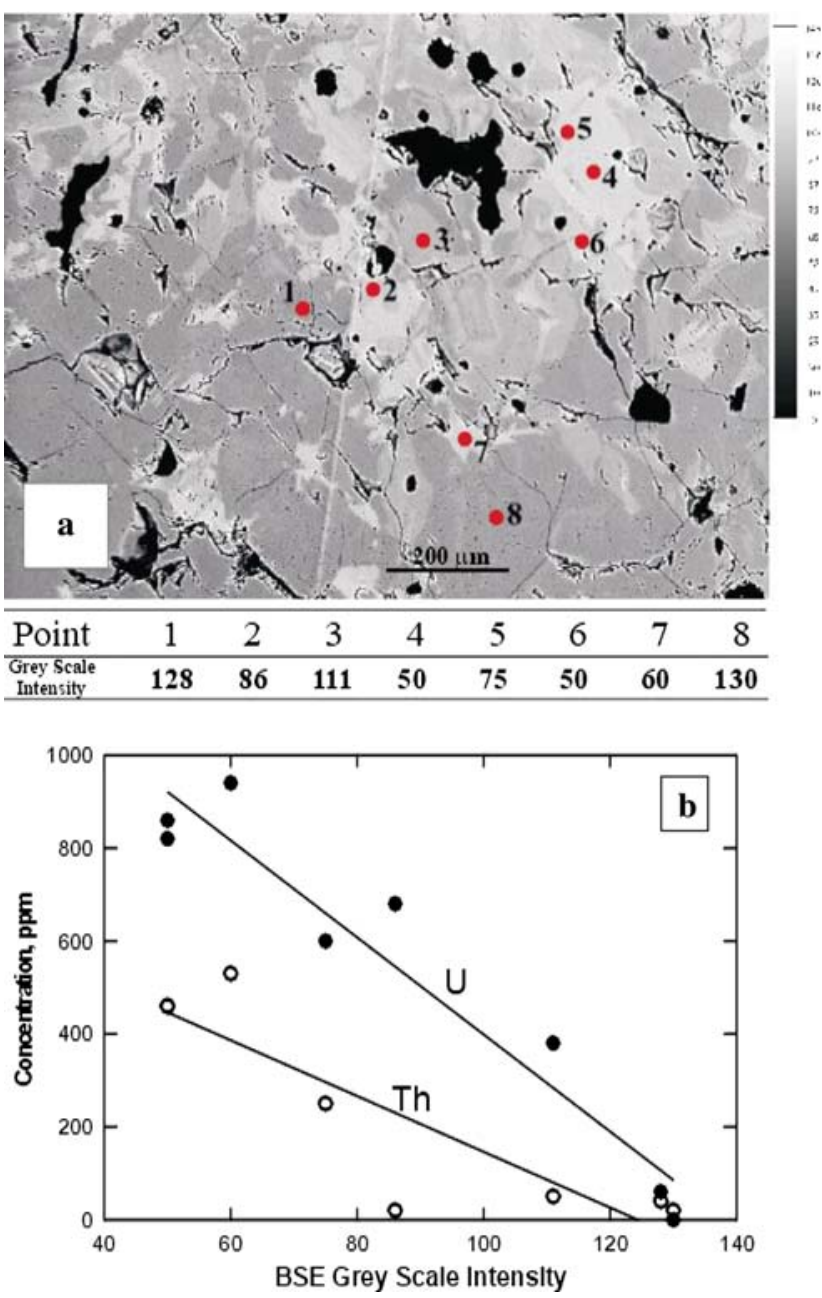

Fig. 6 a Back-scattered electron (BSE) image of Tambani zircon, showing irregular, patchy domains of variable BSE brightness. Bright regions correspond to areas with higher mean atomic number, dominantly caused by higher concentrations of $\mathrm{U}$ and $\mathrm{Th}$, as shown in b. Numbers in a refer to locations of electron microprobe spot analyses given in Table 2. b Plot of BSE grey scale intensity versus concentration of $\mathrm{U}$ (solid symbols) or Th (open symbols) concentrations determined by microprobe

discordance (Table 4) with a mean ${ }^{207} \mathrm{~Pb} /{ }^{206} \mathrm{~Pb}$ age of $724.5 \pm 0.7 \mathrm{Ma}$, and three other analyses plot in a second more discordant cluster. Of the three monazite grains analysed, two had very low U contents of 5$6 \mathrm{ppm}$ (and high $\mathrm{Th} / \mathrm{U}$ of $120-180$ ) and do not yield useful age data (not reported in Table 4). The third grain, however, had $57 \mathrm{ppm} \mathrm{U}$ and sufficient radiogenic $\mathrm{Pb}$ to provide a reasonable age indication (Table 4). Because of the high $\mathrm{Th} / \mathrm{U}$ ratio of 112 , and the likely ${ }^{230} \mathrm{Th}$ excess, it is probable that the ${ }^{206} \mathrm{~Pb} /{ }^{238} \mathrm{U}$ ratio is too high (Schärer 1984) and the ${ }^{207} \mathrm{~Pb} /{ }^{235} \mathrm{U}$ age of $522 \pm 17 \mathrm{Ma}$ is preferred.

By themselves the eight zircon analyses define a line with an upper intercept age of $726 \pm 6 \mathrm{Ma}$ and a lower 


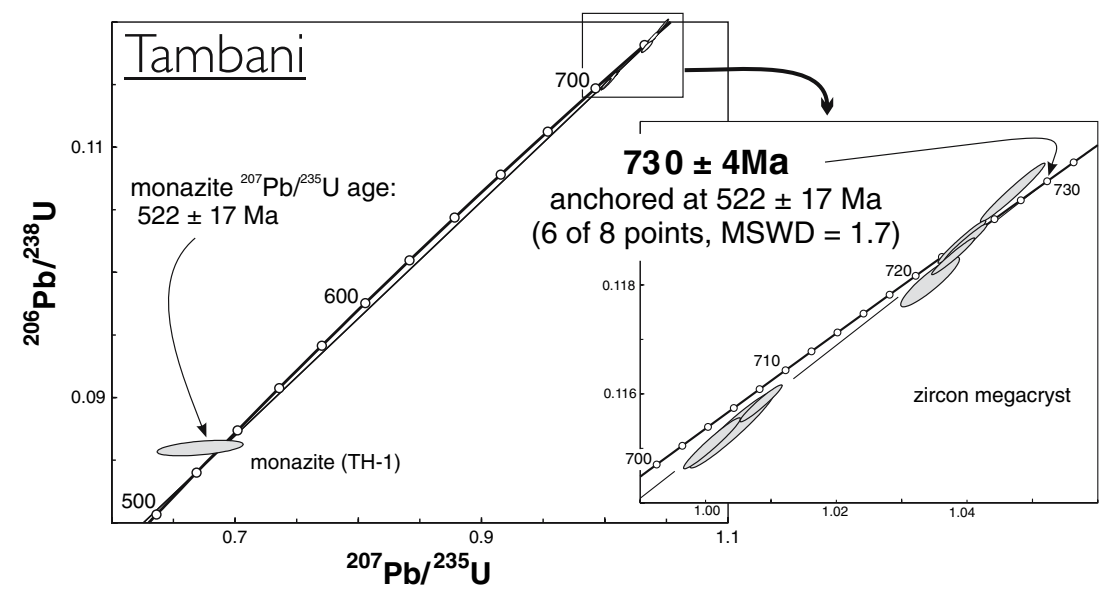

Fig. 7 Concordia diagram showing TIMS analyses of fragments from a single Tambani zircon megacryst and a monazite grain from gneiss sample TH-1. The upper Concordia intercept age of $730 \pm 4 \mathrm{Ma}$ is interpreted to represent the time of magmatic

intercept age of $459 \pm 150 \mathrm{Ma}$, but with a high MSWD of 5.4. The upper intercept age increases marginally to $728 \pm 6$ Ma but the MSWD remains the same if the zircon line is anchored at the monazite age of $522 \pm$ $17 \mathrm{Ma}$. The excess scatter is due mainly to the deviation of two zircon analyses, one of which is reversely discordant and a second which plots slightly below the line. The latter one is somewhat suspect because of high common $\mathrm{Pb}(1.2 \mathrm{ppm})$, whereas there is no immediately apparent reason for the reverse discordance of the other data point. The omission of these two analyses from the calculation improves the fit, defining an upper intercept age of $730 \pm 4 \mathrm{Ma}$, which is taken as the best estimate for the primary crystallization of the zircons.

The monazite age of $522 \pm 17 \mathrm{Ma}$ is interpreted as the time of formation of monazite during amphibolite grade metamorphism. This event caused partial Pb-loss in some domains of the zircon, presumably related to the recrystallization features seen in the CL-images. This is exemplified by the most discordant SHRIMP analysis of patchy zircon (see below), interpreted as representing partial $\mathrm{Pb}$-loss during metamorphism, and collinear with the discordant TIMS data.

\section{U-Pb geochronology (SHRIMP)}

Locations of spot analyses by SHRIMP are shown in Fig. 5; results are plotted on a Concordia diagram in Fig. 8. Data for regions of zircon interpreted as magmatic yield ${ }^{206} \mathrm{~Pb}^{*} /{ }^{238} \mathrm{U}$ ages between $712 \pm 9 \mathrm{Ma}$ (Spot 16) and $735 \pm 10 \mathrm{Ma}$ (Spots 12, 13). Patchy, crosscutting vein-like material and peculiar agate-like zircon regions, although obviously texturally younger, crystallization of the original nepheline-bearing rocks, and the ${ }^{207} \mathrm{~Pb} /{ }^{235} \mathrm{U}$ age of $522 \pm 17 \mathrm{Ma}$ for monazite is an indication for the time of recrystallization during deformation and amphibolite facies metamorphism

surprisingly yield ages between $732 \pm 11 \mathrm{Ma}$ (Spot 22) and $742 \pm 14 \mathrm{Ma}$ (Spot 14). We interpret this to indicate that these zircon types represent late-stage magmatic alteration and possible recrystallization, with ages unresolvable from the magmatic crystallization age. Analyses of zircon with these textural features, therefore, conform to a single population, for which a Concordia age of $728.7 \pm 6.5 \mathrm{Ma}$ can be calculated $($ MSWD $=0.37)$. This result is indistinguishable from the TIMS upper intercept age of $730 \pm 4$ Ma. Two analyses of zircon characterized by patchy regions with very bright CL emission (Spots 21, 24) are compromised by poor count rates caused by low $\mathrm{U}$ concentrations, and give imprecise ${ }^{206} \mathrm{~Pb}^{*} / 238 \mathrm{U}$ dates (Table 5), although spot 21 (with only 5 ppm U) appears to record an age distinctly younger $(657 \pm 22 \mathrm{Ma})$ than that of magmatic crystallization. This could be indicative of partial $\mathrm{Pb}$-loss in recrystallized zones. A single analysis (Spot 20) of zircon showing randomly distributed patches with variable CL emission, however, shows a significantly younger ${ }^{206} \mathrm{~Pb}^{*} / 238 \mathrm{U}$ age of $593 \pm 8 \mathrm{Ma}$. This age might correspond to a specific event (such as amphibolite-grade metamorphism) associated with heterogeneous, patchy recrystallization or reworking of the original zircon, or might represent partial $\mathrm{Pb}$-loss during an event younger than $593 \mathrm{Ma}$. More SHRIMP data are needed to resolve the metamorphic age of the Tambani zircons.

\section{Lu-Hf isotopes}

The Lu-Hf whole-rock isotopic data for Tambani nepheline-bearing gneisses allow a 3-point regression (Fig. 9) corresponding to an age of $584 \pm 17 \mathrm{Ma}$ 


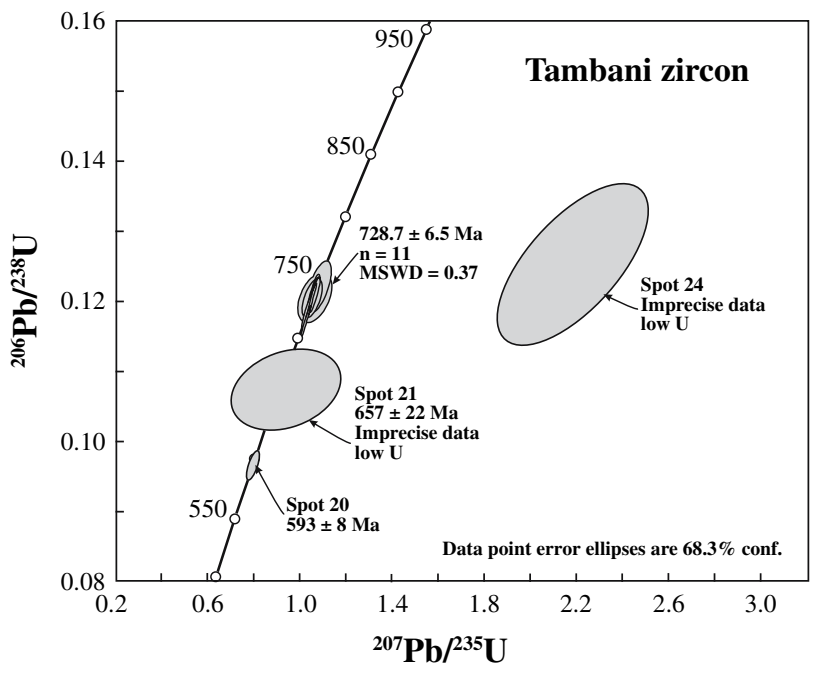

Fig. 8 Concordia diagram showing SHRIMP analyses of spots shown in the images of Figs. 4 and 5. The cluster of 11 analyses at $728.7 \pm 6.5 \mathrm{Ma}$ is within error of the TIMS upper intercept age of $730 \mathrm{Ma}$, and is interpreted as representing the time of magmatic crystallization. The large error circles for spots 21 and 24 are caused by imprecise data due to low $U$ concentrations. The age of $593 \pm 8 \mathrm{Ma}$ for spot 20 might represent partial $\mathrm{Pb}$-loss during a younger metamorphic event

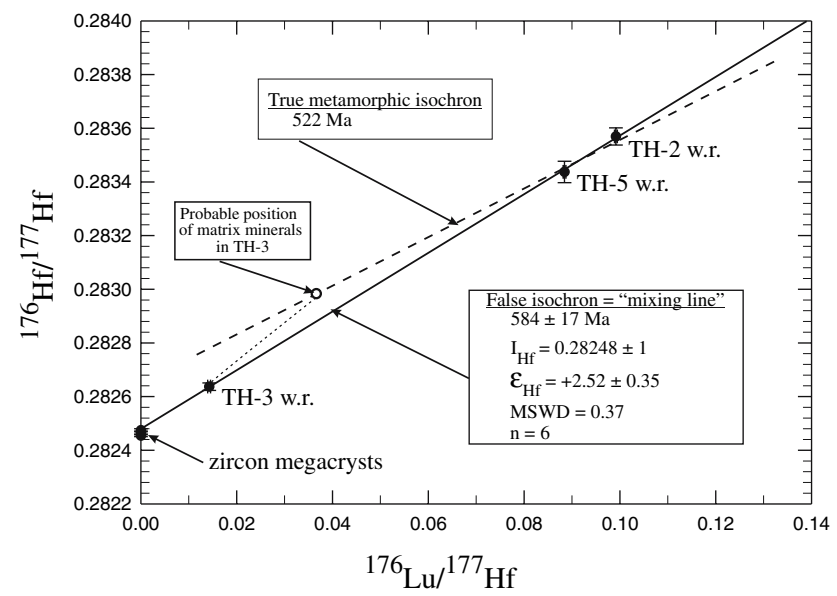

Fig. $9 \mathrm{Lu}-\mathrm{Hf}$ isotopic data for Tambani nepheline-bearing gneisses and zircon megacrysts. The data yield a linear array that we interpret as a mixing line, with the variability in wholerock isotopic compositions representing variable (but small) amounts of zircon. A hypothetical zircon-free position for sample TH-3 is indicated as an open circle. If regressed with the two other whole-rock samples, this would yield an isochron representing the time of amphibolite-grade metamorphism (522 Ma, as indicated by the monazite TIMS analysis)

(MSWD $=0.37)$. This is considerably younger than the age of $730 \pm 4 \mathrm{Ma}$, interpreted as representing magmatic crystallization, and indicates the Lu-Hf wholerock isotopic system has been at least partially reset, probably during amphibolite-grade metamorphism. Interestingly, Lu-Hf isotopic data for the zircon megacrysts plot within error of the $y$-intercept of the whole-rock regression, assuming that the zircons have $\mathrm{Lu} / \mathrm{Hf}=0$ (which is reasonable, given the measured $\mathrm{Hf}$ concentrations of 4,494-7,802 ppm, and the expected $\mathrm{Lu}$ concentrations of less than about $10 \mathrm{ppm}$, based on concentrations of other REE; see Table 1). Given that the zircon megacrysts preserve a predominantly magmatic age of $730 \mathrm{Ma}$, their position at the $y$-intercept of a substantially younger Lu-Hf regression requires explanation. This is discussed below.

\section{Discussion}

\section{Age interpretations}

We consider the upper intercept U-Pb TIMS zircon age of $730 \pm 4 \mathrm{Ma}$ and the coeval mean SHRIMP age of $729 \pm 7 \mathrm{Ma}$ to represent the time of magmatic crystallization of the Tambani nepheline-bearing rocks. Evidence includes the concordance to near-concordance of data points (Figs. 7, 8), the euhedral shape of the zircons (Fig. 3), the regular, crystallographically controlled oscillatory growth zoning and the absence of cores in the CL images that could imply the presence of an inherited component in the grains (Fig. 4).

Our best indication for the time of amphibolite grade metamorphism and gneissic deformation is given by the monazite ${ }^{207} \mathrm{~Pb} /{ }^{235} \mathrm{U}$ age of $522 \pm 17 \mathrm{Ma}$, also supported by the distinct discordance of some of the zircon data, which by themselves indicate $\mathrm{Pb}$-loss during a Paleozoic event.

The intermediate age of $584 \pm 17$ Ma obtained from regression of the Lu-Hf isotopic data requires explanation. It seems unlikely that the Lu-Hf "isochron" could represent a temperature-controlled diffusive exchange of Hf between zircon and whole-rocks (which can be considered as "matrix" material), because Hf should be quite retentive in the zircon structure (e.g. Cherniak and Watson 2003), certainly more so than Pb, which does not seem to have been substantially lost from the zircon megacrysts, given their predominant preservation of magmatic ages. Therefore, the Lu-Hf "isochron" probably does not represent a true reset metamorphic isochron, and the age of $584 \pm 17 \mathrm{Ma}$ may have no geological meaning.

A possible explanation is that the linear array represents a mixing line between zircon (with very low $\mathrm{Lu} / \mathrm{Hf}$ ) and other minerals in the "matrix" (mica, feldspar, nepheline) with higher Lu/Hf. The array is defined by whole-rock samples that contain variable 
(but generally very small) amounts of zircon, with sample TH-3 containing the largest modal proportion of zircon. This is supported by the higher concentration of $\mathrm{Lu}$ and $\mathrm{Hf}$ in TH-3 (by a factor of about 10 ) relative to whole-rock samples TH-2 and TH-5 (Table 3). In this model, as illustrated in Fig. 9, the "true" metamorphic isochron, which resulted from $\mathrm{Lu}$ and $\mathrm{Hf}$ exchange between matrix minerals but not zircon, must be younger, perhaps $522 \mathrm{Ma}$ as indicated by the monazite (Fig. 7). Thus, we suggest that the true position of the matrix minerals in $\mathrm{TH}-3$ might lie on this younger isochron, at higher ${ }^{176} \mathrm{Lu} /{ }^{177} \mathrm{Hf}$ and ${ }^{176} \mathrm{Hf} /{ }^{177} \mathrm{Hf}$ than the measured isotopic composition of the sample (Fig. 9). In any case, our data imply that the Lu-Hf isotopic system is resettable at amphibolite facies conditions.

\section{Tectonic implications}

We interpret the magmatic crystallization age of $730 \pm$ $4 \mathrm{Ma}$ for the Tambani body to represent a time of intra-continental rifting. This is consistent with the timing of the initial break-up of the Rodinia supercontinent, which is postulated to have started at 725-750 Ma (Powell et al. 1993; Torsvik et al. 1996). Although the timing of this rifting seems well established, there is no such certainty about the relative positions in Rodinia reconstructions of some continental blocks, such as the Kalahari Craton; this awaits more robust palaeomagnetic data (Torsvik 2003). Spatial relationships between the rifting event that we have discerned in southern Malawi and similarly aged events in Baltica, Laurentia and other postulated Rodinian blocks cannot at present be established. PanAfrican-aged deformed carbonatites and nepheline gneisses (DARCs) outcrop in the Zambezi valley and in northern Malawi close to the edge of the Congo Craton (Fig. 1) (Burke et al. 2003, their Fig. 1 and Table 1). Geochronological work of the kind reported in this paper will be required on rocks and minerals from those bodies before a more complete understanding of the operation of Wilson cycle processes in central, eastern and southern Africa can be established.

Following the model of Burke et al. (2003), we interpret the amphibolite grade metamorphism and deformation of the Tambani occurrence to have taken place during continental collision within what has come to be designated as the East African Orogen, in those parts of Gondwana that experienced the Pan-African orogeny (Stern 1994; Shackleton 1996; Muhongo et al. 2001). Available metamorphic U-Pb zircon ages obtained for amphibolite to granulite facies basement gneisses from southern Malawi (549-571 Ma, Kröner et al. 2001) are somewhat older than our monazite age of $522 \pm 17 \mathrm{Ma}$. However, metamorphism in the East African Orogen is known to be diachronous (e.g. Sommer et al. 2003), and there may be several collisional events, the complexities of which are only now beginning to be worked out. We note with interest that in nearby northern Mozambique, Ingram et al. (2005) report metamorphic zircon overgrowths as young as $505 \mathrm{Ma}$ for deformed Kibaran granitoids, and Grantham et al. (2005) have determined concordant zircon ages of $453 \pm 17 \mathrm{Ma}$ and $497 \pm 8 \mathrm{Ma}$ for undeformed granites. Further high-precision geochronology is needed to resolve the timing of collisional event(s), especially in the southern part of the East African Orogen.

\section{Conclusions}

Euhedral zircon megacrysts in miaskitic biotite-nepheline monzodiorite gneisses from the Tambani body, southern Malawi, are magmatic crystallization products that largely survived amphibolite grade metamorphism.

The upper Concordia intercept age of $730 \pm 4 \mathrm{Ma}$ represents the time of magmatic crystallization, which we interpret to record a continental rifting event associated with the Neoproterozoic break-up of the Rodinia supercontinent.

The monazite ${ }^{207} \mathrm{~Pb} /{ }^{235} \mathrm{U}$ age of $522 \pm 17 \mathrm{Ma}$ is interpreted as the time of amphibolite facies metamorphism and deformation. This may mark the time of Pan-African collisional suturing events associated with the assembly of East and West Gondwana in the southern part of the East African Orogen. Additional geochronology is needed to confirm this.

Our data indicate that the whole-rock Lu-Hf isotopic system is partially resettable at amphibolite facies metamorphic conditions. Care must be taken when interpreting age and initial ratio information from $\mathrm{Lu}-$ Hf whole-rock isotopic systems in metamorphosed terranes.

Deformed, zircon-bearing alkaline rocks (and carbonatites) appear to preserve a record of rifting and collisional events, and can be used to constrain Wilson cycle processes on a regional scale.

Acknowledgments We are indebted to Mike Moles and Brian Chiomba of Millennium Mining (Malawi) for introducing us to, and sponsoring our work on the alkaline rocks of southern Malawi. Sharon Turner performed the XRF analyses, and Lynette Greyling helped with some of the CL imagery. Sharad Master educated us on current work in the mobile belts of southern Africa. Reviews by Don Davis and John Hanchar improved the paper substantially. 


\section{References}

Ahrens LH, Erlank AJ (1969) Hafnium. Sections B-O, Handbook of Geochemistry II/5. Springer, Berlin Heidelberg New York

Bailey DK (1974) Continental rifting and alkaline magmatism. In: Sørenson H (ed) The alkaline rocks. Wiley, New York, pp 148-159

Bailey DK (1977) Lithospheric control of continental rift magmatism. J Geol Soc Lond 133:103-108

Bailey DK (1992) Episodic alkaline activity across Africa: implications for the causes of continental break-up. In: Storey BC et al. (eds) Magmatism and the causes of continental break-up. Geol Soc London Spec Publ 68, pp 91-98

Blichert-Toft J, Chauvel C, Albarède F (1997) Separation of Hf and $\mathrm{Lu}$ for high precision isotope analysis of rock samples by magnetic sector-multiple collector ICP-MS. Contrib Mineral Petrol 127:248-260

Burke K, Ashwal LD, Webb SJ (2003) New way to map old sutures using deformed alkaline rocks and carbonatites. Geology 31:391-394

Cherniak D and Watson EB (2003) Diffusion in zircon. In: Hanchar JM, Hoskin PWO (eds) Zircon. Rev Mineral Geochem 53, pp 469-500

Cooper WGG, Bloomfield K (1961) The geology of the Tambani-Salambidwe area (with accompanying geological map, scale 1:100,000). Bull 13, Geol Surv Nyasaland, 63 pp

Corfu F, Hanchar JM, Hoskin PWO, Kinny P (2003) Atlas of zircon textures. In: Hanchar JM, Hoskin PWO (eds) Zircon. Rev Mineral Geochem 53, pp 469-500

Feather CE, Willis JP (1976) A simple method for background and matrix correction of spectral peaks in trace element determination by X-ray fluorescence spectrometry. X-ray Spectrom 5:41-48

Garson MS (1965) Carbonatites in southern Malawi. Geol Surv Malawi Bull 15, 128 pp

Gellatly DC, Hornung G (1968) Metasomatic nepheline-bearing gneisses from Darkainle, Somali Republic. J Geol 76:678-691

Grantham GH, Keidan H, Hokada T, Ingram BA, Shiraishi K, Kagashima S, Azevedo S (2005) New U/Pb SHRIMP zircon data from NE Mozambique and implications for the evolution of the Mozambique Belt (abstract). Geo2005, Geol Soc So Afr Ann Meeting, Univ KwaZulu-Natal, Durban, 4-7 July 2005, pp 92-93

Ingram BA, Macey PH, Grantham GH, Cronwright MS, de Kock GS, Roberts MP, Armstrong RA, Manhiça V (2005) Structure of the Kibaran and Pan African Nampula Subprovince in northern Mozambique (abstract). Geo2005, Geol Soc So Afr Ann Meeting, Univ KwaZulu-Natal, Durban, 4-7 July, 2005, pp 115-116

Johnston ST, Burke K, Ashwal LD, Webb SJ (2003) Examples of deformed alkaline rocks and carbonatites (DARCs) in suture zones and as sources of alkaline rocks and carbonatites (ARCs) in overlying rifts from the northwestern Cordilleran continental margin and elsewhere (abstract). Geol Soc Am Abstr Prog 35(6):559

Kitajima LFW, Ruiz J, Gehrels G, Gaspar JC (2001) Uraniumlead ages of zircon megacrysts and zircon included in corundum from Peixe Alkaline Complex (Brazil) (abstract). Simposio Sul Americano de Geologia de Isotopos, 3 (III SSAGI), Pucón, Chile, Extended Abstracts on CD-ROM

Krogh TE (1973) A low contamination method for hydrothermal decomposition and extraction of $\mathrm{U}$ and $\mathrm{Pb}$ for isotopic age determinations. Geochim Cosmochim Acta 37:485-494
Krogh TE (1982) Improved accuracy of U/Pb zircon ages by creation of more concordant systems using air abrasion technique. Geochim Cosmochim Acta 46:637-649

Kröner A, Willner AP, Hegner E, Jaeckel P, Nemchin AA (2001) Single zircon ages, PT evolution and $\mathrm{Nd}$ isotopic systematics of high-grade gneisses in southern Malawi and their bearing on the evolution of the Mozambique belt in southern Africa. Precambrian Res 109:3-4

Ludwig KR (1998) On the treatment of concordant uranium-lead ages. Geochim Cosmochim Acta 62:665-676

Ludwig KR (1999) Using ISOPLOT/Ex 2.01: a geochronological toolkit for Microsoft Excel, Spec. Pub. 1A, Berkeley Geochronology Center, $46 \mathrm{pp}$

Ludwig KR (2000) SQUID 1.00: a user's manual. Spec. Pub. 2, Berkeley Geochronology Center, $17 \mathrm{pp}$

McCulloch MT, Rosman KJR, De Laeter JR (1977) The isotopic and elemental abundance of ytterbium in meteorites and terrestrial samples. Geochim Cosmochim Acta 41:17031707

Miyazaki T, Santosh M (2005) Cooling history of the Puttetti alkali syenite pluton, southern India. Gondwana Res 8:567574

Muhongo S, Kröner A, Nemchin AA (2001) Single zircon evaporation and SHRIMP ages for granulite facies rocks in the Mozambique belt of Tanzania. J Geol 109:171-189

Münker C, Weyer S, Scherer E, Metzger K (2001) Separation of high field strength elements $(\mathrm{Nb}, \mathrm{Ta}, \mathrm{Sr}, \mathrm{Hf})$ and $\mathrm{Lu}$ from rock samples for MC-ICPMS measurements. Geochemistry, Geophysics and Geosystems $\left(\mathrm{G}^{3}\right)$, vol 2, no 12, DOI 10.1029/2001GC000183, 14 December 2001

Murali AV, Parthasarathy R, Mahadevan TM, Sankar Das M (1983) Trace element characteristics, REE patterns and partition coefficients of zircons from different geological environments-a case study on Indian zircons. Geochim Cosmochim Acta 47:2047-2052

Nair NGK, Santosh M (1985) Geochemistry and petrogenesis of the Puttetti syenite, South India. Neues Jahrbuch Mineral Abh 151:213-227

Nicolaysen LO, Burger AJ (1965) Note on an extensive zone of 1000 million-year old metamorphic and igneous rocks in southern Africa. Sciences de la Terre 10(3-4):497-516

Norrish K, Hutton JT (1969) An accurate X-ray spectrographic method for the analysis of a wide range of geological samples. Geochim Cosmochim Acta 33:431-453

Paces JB, Miller JD (1993) Precise U-Pb ages of Duluth Complex and related mafic intrusions, northeastern Minnesota: Geochronological insights to physical, petrogenetic, paleomagnetic and tectonomagmatic processes associated with the $1.1 \mathrm{Ga}$ mid-continent rift system. J Geophys Res 98B:13997-14013

Parrish RR, Noble SR (2003) Zircon U-Th-Pb geochronology by isotope dilution-thermal ionization mass spectrometry (ID-TIMS). In: Hanchar JM, Hoskin PWO (eds) Zircon. Rev Mineral Geochem 53:183-213

Parrish RR, Scammell RJ (1988) The age of the Mount Copeland syenite gneiss and its metamorphic zircons, Monashee complex, southeastern British Columbia. In: Report 2, Geol Surv Canada Pap 88-2, pp 21-22

Patchett PJ, Tatsumoto M (1980) A routine high-precision method for Lu-Hf isotope geochemistry and chronology. Contrib Mineral Petrol 75:263-267

Pedersen RB, Dunning GR, Robins B (1989) U-Pb ages of nepheline syenite pegmatites from the Seiland Magmatic Province, N Norway. In: Gayer RA (ed) The Caledonide Geology of Scandinavia. Graham \& Trotman, pp 3-8 
Pouchou JL, Pichoir F (1984) A new model for quantitative Xray microanalysis. Part 1: application to the analysis of homogeneous samples. La Recherche Aerospatiale 3:13-18

Pouchou JL, Pichoir F (1985) “PAP' f(rz) correction procedure for improved quantitative microanalysis. In: Armstrong JT (ed) Microbeam Analysis. San Francisco Press, pp 104-106

Powell CMcA, Li ZX, McElhinny MW, Meert JG, Park JK (1993) Palaeomagnetic constraints of the Neoproterozoic breakup of Rodinia and the Cambrian formation of Gondwana. Geology 21:889-892

Schärer U (1984) The effect of initial ${ }^{230} \mathrm{Th}$ disequilibrium on young $\mathrm{U}-\mathrm{Pb}$ ages: The Makalu case, Himalaya. Earth Planet Sci Lett 67:191-204

Scherer E, Münker C, Metzger K (2001) Calibration of the lutetium-hafnium clock. Science 293:683-687

Scogings AJ, Forster IF (1989) Gneissose carbonatites in the Bull's run complex, Natal. S Afr J Geol 92:1-10

Shackleton RM (1996) The final collision zone between East and West Gondwana: where is it? J Afr Earth Sci 23:271-287

Sommer H, Kröner A, Hauzenberger C, Muhongo S, Wingate MTD (2003) Metamorphic petrology and zircon geochronology of high-grade rocks from the central Mozambique Belt of Tanzania: crustal recycling of Archean and Palaeoproterozoic material during the Pan-African orogeny. J Metamorph Geol 21:915-934

Stacey JS, Kramers JD (1975) Approximation of terrestrial lead isotope evolution using a two-stage model. Earth Planet Sci Lett 26:221-297
Stern RJ (1994) Arc assembly and continental collision in the Neoproterozoic East African Orogen: implications for the consolidation of Gondwanaland. Ann Rev Earth Planet Sci 22:319-351

Streckeisen A (1967) To each plutonic rock its proper name. Earth Sci Rev 12:1-33

Sørensen H (ed) (1974) The alkaline rocks. Wiley, London, $622 \mathrm{pp}$

Torsvik TH (2003) The Rodinia jigsaw puzzle. Science 300:1379_ 1380

Torsvik TH, Smethurst MA, Meert JG, Van der Voo R, McKerrow WS, Brasier MD, Sturt BA, Walderhaug HJ (1996) Continental break-up and collision in the Neoproterozoic and Palaeozoic: a tale of Baltica and Laurentia. Earth Sci Rev 40:229-258

Williams IS (1998) U-Th-Pb geochronology by ion microprobe. In: McKibben MA, Shanks WC III, Ridley WI (eds) Applications of microanalytical techniques in understanding mineralizing processes. Rev in Econ Geol 7:1-35

Woolley AR (1987) Alkaline rocks and carbonatites of the world: Part 1, North and South America. University of Texas Press, Austin, $222 \mathrm{pp}$

Woolley AR (1995) Alkaline rocks and carbonatites of the world: Part 2, Former USSR. Chapman and Hall, London, $226 \mathrm{pp}$

Woolley AR (2001) Alkaline rocks and carbonatites of the world: Part 3, Africa. Geological Society of London, 372 pp 